\section{'Sunbelt', A New Juice Grape for the South-central United States}

\author{
James N. Moore', Justin R. Morris ${ }^{2}$, and John R. Clark ${ }^{3}$ \\ Department of Horticulture and Forestry, University of Arkansas, Fayetteville, \\ AR 72701
}

Additional index words. Vitis labrusca, fruit breeding

The Arkansas Agricultural Experiment Station announces the release of a new juice grape (Vitis labrusca L.) cultivar, 'Sunbelt', which fulfills the need for a processing grape that can be grown in southern areas where 'Concord' grapes display uneven fruit ripening associated with high temperatures (Cawthon and Morns, 1983). 'Sunbelt' ripens evenly under the climatic conditions of extreme southern Arkansas and should perform well under similar conditions in other southern states. However, the reaction of' Sunbelt' to Pierce's disease in Gulf Coast areas is not known.

\section{Origin}

'Sunbelt' originated from open-pollinated seeds collected from 'Concord' grapes in 1968. It was selected from a seedling field in 1971 and has been tested as Ark. 1335. Tests were conducted at four locations in Arkansas (Fayetteville, Clarksville, Bald Knob, and Hope), in several other states, and in southern Brazil.

\section{Description}

'Sunbelt' is similar to 'Concord' in most plant and fruit characteristics (Fig. 1), differing primarily in its ability to ripen more evenly

Received for publication 18 Dec. 1992. Accepted for publication 19 Mar. 1993. Published with the approval of the director of the Arkansas Agricultural Experiment Station. We thank Bruce Bordelon, Maurus Brown, Don Dombek, Gina Fernandez, Kelly Irvin, Elbert Baker, Charles Parsons, and Jack Young for collecting data during the evaluation of 'Sunbelt'. The cost of publishing this paper was defrayed in part by the payment of page charges. Under postal regulations, this paper therefore must be hereby marked advertisement solely to indicate this fact.

'Distinguished Professor of Horticulture.

${ }^{2}$ University Professor of Food Science.

${ }^{3}$ Associate Professor and Resident Director, Fruit Substation.

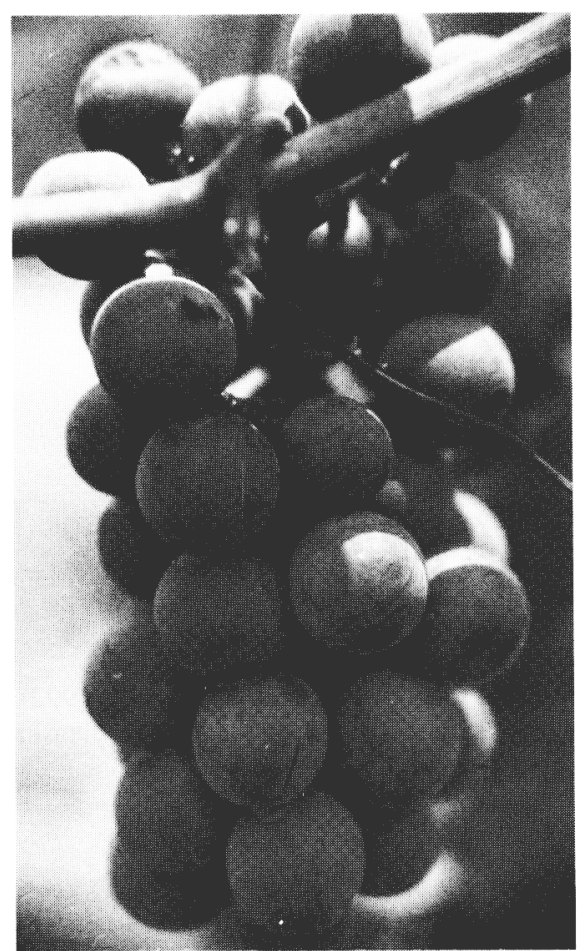

Fig. 1. 'Sunbelt' grapes.
Planted 1985; means of 5 years, 1988-92.

Planted 1985; means of 5 years, 1987-89, 1991, 1992.

'Planted 1985; means of 5 years, 1987-90, 1992.

'Planted 1988; means of 3 years, 1990-92. under high temperatures. Plants are moderately productive; clusters are small; berries are blue, large, and seeded; and soluble solids concentration (SSC) and harvest date correspond closely with those of 'Concord' in areas where' Concord' is grown (Table 1). Vines are moderately resistant to black rot [Guignardia bidwellii (En.) V. \& R.] and anthracnose [Elsinoe ampelina (d.By.) Shear], and are highly resistant to powdery mildew (Uncinula necator-Burr.) and downy mildew (Plasmopora viticola Berl. \& Toni.). In Kansas tests, 'Sunbelt' exhibited sensitivity to the herbicide (2,4-dichlorophenoxy) acetic acid, showing injury similar to that of 'Concord' (E. Hellman, personal communication).

'Sunbelt' grape vines are vigorous, averaging a $1.7-\mathrm{kg}$ pruning weight per year. Vine growth habit and leaf and cane characteristics are similar to those of 'Concord'. While performance on diverse training and pruning systems has not been determined, systems recommended for 'Concord' likely would be applicable to 'Sunbelt', based on the similarity of vigor and growth habit of the two cultivars. The potential for mechanized pruning and shoot positioning of' Sunbelt' is the same as for 'Concord'.

'Sunbelt' matures its wood early in fall and has demonstrated good cold hardiness in Arkansas and Kansas, showing no injury at-24C. In addition, late budbreak (2 Apr. in central Arkansas) and late bloom (5 May) helps avoid spring freeze damage.' Sunbelt' has performed well in the warm, humid climate of Rio Grande do Sul, Brazil (U.A. Camargo, personal communication).

'Sunbelt' grape juice characteristics were similar to or better than those of 'Concord' juice produced commercially by a major national manufacturer (Table 2).' Sunbelt' juice, obtained from grapes grown at the Univ. of

Table 1. Production and fruit characteristics of 'Sunbelt' grapes at four Arkansas locations.

\begin{tabular}{lccccc}
\hline \hline & $\begin{array}{c}\text { Harvest } \\
\text { date } \\
\text { (August) }\end{array}$ & $\begin{array}{c}\text { Yield } \\
\left(\mathrm{t} \cdot \mathrm{ha}^{-1}\right)\end{array}$ & $\begin{array}{c}\text { Cluster } \\
\text { wt } \\
(\mathrm{g})\end{array}$ & $\begin{array}{c}\text { Berry } \\
\text { wt } \\
(\mathrm{g})\end{array}$ & $\begin{array}{c}\text { coluble } \\
\text { solids } \\
\text { concn } \\
(\%)\end{array}$ \\
\hline Location $_{\text {Fayetteville }^{z}}$ & 23 & 9.1 & 180 & 4.4 & 16.1 \\
Clarksville $^{y}$ & 17 & 10.9 & 137 & 4.3 & 16.9 \\
Bald Knob $^{\mathrm{x}}$ & 10 & 5.9 & 146 & 4.2 & 17.3 \\
Hope $^{w}$ & 1 & 6.1 & 128 & 4.6 & 17.2 \\
\hline
\end{tabular}


Table 2. Quality of hot-pressed 'Sunbelt' grape juice compared to a major national brand of 'Concord' grape juice.

\begin{tabular}{|c|c|c|c|c|c|c|c|}
\hline \multirow[b]{2}{*}{ Cultivar } & \multirow{2}{*}{$\begin{array}{c}\text { Soluble } \\
\text { solids } \\
\text { concn } \\
(\%) \\
\end{array}$} & \multirow[b]{2}{*}{$\mathrm{pH}$} & \multirow{2}{*}{$\begin{array}{l}\text { Acidity } \\
\text { as } \\
\text { tartaric } \\
(\%) \\
\end{array}$} & \multicolumn{3}{|c|}{ Color $^{2}$} & \multirow{2}{*}{$\begin{array}{l}\mathrm{OD}^{y} \text { at } \\
520 \mathrm{~nm}\end{array}$} \\
\hline & & & & $\mathrm{L}$ & $\mathrm{a}$ & $\mathrm{b}$ & \\
\hline Concord & 16.3 & 3.42 & 0.67 & 13.8 & 21.0 & 4.5 & 0.174 \\
\hline Sunbelt & 16.4 & 2.97 & 0.86 & 6.4 & 24.0 & 3.4 & 0.469 \\
\hline Significance & NS & & & & * & NS & $* *$ \\
\hline
\end{tabular}

${ }^{2}$ Color determined by Gardner Color Difference Meter.

Optical density; determined by Bausch and Lomb Spectronic 20.

NS.,"*t Nonsignificant or significant at $P \leq 0.05$ or 0.01 , respectively.

Table 3. Mean sensory ratings' for 'Sunbelt' grape juice compared to a major national brand of 'Concord' grape juice.

\begin{tabular}{lcccc}
\hline \hline & \multicolumn{3}{c}{ Intensity } & Overall \\
\cline { 2 - 4 } Cultivar & Color & Aroma & Flavor & acceptability \\
\hline Concord & 6.4 & 6.2 & 6.1 & 6.2 \\
Sunbelt & 8.0 & 7.4 & 6.4 & 6.7 \\
Significance & $*$ & $*$ & NS & NS \\
\hline
\end{tabular}

${ }^{2}$ Rated on a scale of 1 to 10 , with 10 being best.

Ns." Nonsignificant or significant at $P \leq 0.05$, respectively.

Arkansas Fruit Substation, Clarksville, was prepared using procedures that are used by commercial processing plants. The juice composition analyses were conducted as reported by Morris et al. (1986).

Equal in SSC, 'Sunbelt' juice was lower in $\mathrm{pH}$ and higher in acidity (expressed as tartaric acid) than 'Concord' (Table 2), characteristics that would be assets in southern growing re- ing the presence of more monomeric anthocyanin pigments.

Sensory quality was determined with 10 trained panelists, each quality factor being rated on a scale of 1 to 10 , with 10 as most acceptable, using the method of Rathburn and Morris (1990). Color and aroma intensities of 'Sunbelt' juice were rated significantly higher than those of 'Concord' juice (Table 3). There were no differences in the ratings for flavor intensity or overall acceptability.

\section{Availability}

A plant patent application has been submitted for 'Sunbelt'. A list of nurseries licensed to propagate and sell 'Sunbelt' can be obtained from J.N.M.,316 Plant Science Bldg., Univ. of Arkansas, Fayetteville, AR 72701.

\section{Literature Cited}

Cawthon, D.L. and J.R. Morns. 1983. Uneven ripening of 'Concord' grapes. Arkansas Farm Res. 32(1):9.

gions. 'Sunbelt' juice color [Gardner Color Difference Meter (CDM), Silver Spring, Md.] was darker (lower CDM 'L' value) and redder (higher CDM ' $a$ ' value) than that of 'Concord'. The superior color of 'Sunbelt' juice compared to' Concord' was further substantiated by the higher value for acidified optical density (Spectronic 20; Bausch and Lomb, Rochester, N. Y.) at $520 \mathrm{~nm}$, a result suggest-
Morris, J.R, W.A. Sistrunk, J. Junek, and C.A. Sims. 1986. Effects of fruit maturity, juice storage, and juice extraction temperature on quality of 'Concord' grape juice. J. Amer. Soc. Hort. Sci. 111:742-746

Rathburn, I.M. and J.R. Morns. 1990. Evaluation of varietal grape juice-Influence of processing method, sugar and acid adjustment, and carbonation. J. Food Qual. 13:395-409. 